\title{
Mini-review to analyse the phenotype, genotype, and alloantibody titre against Diego antigens in the Chinese population
}

\author{
$\mathrm{Na} \mathrm{Ma}^{1 \Delta}$, Zhiyuan $\mathrm{Xu}^{2 \Delta}$, Yushiang Lin ${ }^{3,4}$, Haochun Chang ${ }^{3,4}$, Xiaofei $\mathrm{Li}^{2}$, Daowang Fan ${ }^{2}$, Yan Qiu,

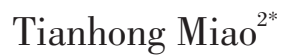 \\ ${ }^{1}$ Department of Transfusion, Yunnan Cancer Hospital \& The Third Affiliated Hospital of Kunming Medical University, \\ Kunming, Yunnan, 650118, China; \\ ${ }^{2}$ Blood Group Lab, Beijing Red Cross Blood Center, Beijing, 100088, China; \\ ${ }^{3}$ Department of Clinical Medicine, School of Basic Medical Sciences, Peking University Health Science Center, Beijing, 100191, China; \\ ${ }^{4}$ The United Reference Laboratory for Blood Group Gene Detection, Jiangsu Libo Medicine Biotechnology Co., Ltd, Jiangyin,
} Jiangsu, 214400, China.

\begin{abstract}
Diego blood antigens are important antigens in Mongoloid people and native South Americans owing to the Dia positivity rate found in these populations. However, the prevalence of $\mathrm{Di}^{\mathrm{a}+}$ is different among native populations of America and China. Our study reviewed the genotype, phenotype, and alloantibody titre of Diego blood group antigens to explain the existence of the dosage effect for Diego antigens. The prevalence of $\mathrm{Di}^{\mathrm{a}+}$ varied from $2.26 \%$ to $10.43 \%$ in the Chinese population was lower than that observed in Native Americans living in USA, Brazil, and Venezuela. The $\mathrm{Di}(\mathrm{a}+\mathrm{b}-) / \mathrm{Di}(\mathrm{a}+\mathrm{b}+)$ ratio in the Chinese was 0.0044 0.0268, which was also lower than that observed in native Americans at 0.0203 0.1628, indicating that the major allele was $\mathrm{Di}(\mathrm{a}+\mathrm{b}+)$ in $\mathrm{Di}^{\mathrm{a}} \mathrm{Chinese}$ or Asians. We also collected $\mathrm{Di}(\mathrm{a}+\mathrm{b}-), \mathrm{Di}(\mathrm{a}+\mathrm{b}+)$, and $\mathrm{Di}(\mathrm{a}-\mathrm{b}+)$ samples from Chinese samples to examine the agglutinin titres with anti-Di ${ }^{\mathrm{a}}$ and anti-Di $\mathrm{i}^{\mathrm{b}}$ and the results supported the existence of the dosage effect for Diego antigens. The agglutinin titres of anti- $\mathrm{Di}^{\mathrm{a}}$ in $\mathrm{Di}(\mathrm{a}+\mathrm{b}+)$ specimens were lower than those in $\mathrm{Di}(\mathrm{a}+\mathrm{b}-)$ specimens, and agglutinin titres of anti- $\mathrm{Di}^{\mathrm{b}}$ in $\mathrm{Di}(\mathrm{a}+\mathrm{b}+)$ specimens were lower than those in $\mathrm{Di}(\mathrm{a}-\mathrm{b}+)$ specimens. Alloantibodies against $\mathrm{Di}^{\mathrm{a}}$ and $\mathrm{Di}^{\mathrm{b}}$ antigen are majorly responsible for haemolytic disease of the new-born and anti- $\mathrm{Di}^{\mathrm{a}}$ reactions resulting in stillborn foetus and transfusion reactions, such as fever and rash, were also reported in the Chinese population.
\end{abstract}

Keywords: Diego antigens, phenotype, genotype, alloantibody

\section{BACKGROUND}

In 1956, the first case of haemolytic disease of new-born (HDN) induced by anti-Di ${ }^{\mathrm{a}}$ was reported in

\footnotetext{
$\Delta$ These authors contributed equally to this work.

*Correspondence to: Tianhong Miao, Blood Group Lab, Beijing Red Cross Blood Center, Beijing, 100088, China. TEL: +86-10-82807272; E-mail: tianhongm@163.com.

The authors state that there is no conflict of interest associated with this publication.
}

Venezuela and HDN caused by anti-Di ${ }^{\mathrm{b}}$ was reported in $1967^{[1,2]}$. The Diego group has been ranked 10th among erythrocytic groups by the International Society of Blood Transfusion (ISBT). The Diego group comprises of 22 antigens located at Band 3, which are encoded by the SLC4A1 gene located at 17q12-q21. These 22 antigens grouped to Diego result from single nucleotide polymorphisms (SNPs) at the SLC4AI gene. The $\mathrm{Di}^{\mathrm{a}} / \mathrm{Di}^{\mathrm{b}}$ result from an SNP at nt.2561 of the $S L C 4 A 1$ gene, meaning that the nucleotide was 
$2561 \mathrm{C}$ for the $\mathrm{Di}^{\mathrm{b}}$ antigen and $2561 \mathrm{~T}$ for the $\mathrm{Di}^{\mathrm{a}}$ antige $^{[3-5]} \cdot \mathrm{Di}^{\mathrm{a}}$ and $\mathrm{Di}^{\mathrm{b}}$ are the most important antigens in the Diego group that cause problems during clinical blood transfusions ${ }^{[6]}$. The frequency of the $\mathrm{Di}^{\mathrm{b}}$ antigen is very high and is found in individuals of all ethnicities, while $\mathrm{Di}^{\mathrm{a}}$ occurs almost exclusively among native South Americans and Mongoloid people and is very rare in people of European origin.

Since the 22 antigens of the Diego group result from SNPs, molecular genotyping is a useful method to examine the SNPs and identify the Diego antigens. Although monoclonal antibodies against $\mathrm{Di}^{\mathrm{a}}$ and $\mathrm{Di}^{\mathrm{b}}$ antigens are available in commercial kits, these kits were unpopular since the $\mathrm{Di}^{\mathrm{a}}$ antigen is only distributed among specific races and $\mathrm{Di}^{\mathrm{b}}$ occurs in all ethnic populations $^{[7,8]}$. Therefore, there are few studies that discuss the dosage effect of Diego antigens. Since the $\mathrm{Di}^{\mathrm{a}}$ antigen is a necessary antigen in screening or panel cells, and the $\mathrm{Di}(\mathrm{a}-\mathrm{b}-)$ phenotype has not been published, we investigated the agglutinin titre in individuals with the genotypes, $\operatorname{Di}(a-b+), D i(a+b+)$, and $\operatorname{Di}(a+b-)$ (a very rare combination of alleles) and calculated the frequency of $\operatorname{Di}(a-b+), \operatorname{Di}(a+b+)$ and $\mathrm{Di}(\mathrm{a}+\mathrm{b}-)$ in the Chinese population from the $\mathrm{Di}^{\mathrm{a}+}$ rate by using monoclonal anti- $\mathrm{Di}^{\mathrm{a}[9]}$.

Previous reports found that alloantibodies against $\mathrm{Di}^{\mathrm{a}}$ induced HDN and delayed haemolytic transfusion reaction, while anti-D $\mathrm{i}^{\mathrm{b}}$ caused delayed haemolytic transfusion reaction ${ }^{[10,11]}$. Our study reviewed an original case report from China to discuss clinical problems caused by alloantibodies against $\mathrm{Di}^{\mathrm{a}}$ and $\mathrm{Di}^{\mathrm{b}}$.

The aim of this study was to review the phenotype and genotype of Diego antigens and the alloantibody response against Diego antigens in the Chinese population. We also compared the present study with European or American and discussed the existence of dosage effect for Diego antigens.

\section{PHENOTYPE}

Although monoclonal antibody anti-Di ${ }^{\mathrm{a}}$ and anti$\mathrm{Di}^{\mathrm{b}}$ are commercially available, various distribution of Diego antigens in different area and ethnics were limited the $\mathrm{mAb}$ widely used in clinics. $\mathrm{Di}^{\mathrm{a}}$ antigen distribution is limited to Native Americans and the Mongoloid people, and other ethnic were very low frequency, while the $\mathrm{Di}^{\mathrm{b}}$ antigen shows a very high prevalence in people of all ethnicities. This irregular distribution results in difficulties in the availability of the appropriate commercial kit. Recent studies investigated the frequency of Diego antigens using monoclonal anti-Di ${ }^{\mathrm{a}}$ and screened rare banks for $\mathrm{Jk}(\mathrm{a}-\mathrm{b}-)$ using monoclonal anti-Di ${ }^{\mathrm{b}}$. One such study published the positive rates of $\mathrm{Di}(\mathrm{a}-\mathrm{b}+)$ from blood donors and consequently inferred the frequencies of phenotype.

We reviewed recent studies on $\mathrm{Di}^{\mathrm{a}}$ frequency and calculated the frequency of $\operatorname{Di}(a+b-), \operatorname{Di}(a+b+)$, and $\operatorname{Di}(\mathrm{a}-\mathrm{b}+)($ Table 1). In China, the Han population in north China showed the highest frequency of $\mathrm{Di}^{\mathrm{a}+}, 11.03 \%$, followed by $8.04 \%$ in blood donors from Shanghai, $5.03 \%$ in the Zang minority, $4.36 \%$ in the Zhuang minority in southeast China, $4.02 \%$ in Koreans in north China, $3.33 \%$ in the Manchu minority, $2.53 \%$ in the Han population in Taiwan, $2.26 \%$ in the Dong minority in southeast China, and $1.43 \%$ in the Taiwanese minority (Table 1). In Asia, the Dia positivity rate was $10.05 \%$ among the Japanese, followed by $6.14 \%$ in Koreans living in Korea, and $4.00 \%$ in Indians living in India. Native Americans from Brazil and Venezuela showed the highest positivity rates for $\mathrm{Di}^{\mathrm{a}}$, showing: $75.71 \%$ in the Parakanã, $54.16 \%$ in the Kaingang, $35.54 \%$ in the Carib, $10.81 \%$ in the Chippewa, $8.03 \%$ in the Penobscot, and $5.26 \%$ in the Arawak populations. The Mexicans and Inuits also showed a higher positivity rate for $\mathrm{Di}^{\mathrm{a}}$, the rate was $10.21 \%$ in Mexicans and $20.93 \%$ for Inuits. From the $\mathrm{Di}^{\mathrm{a}}$ positivity rate, the frequency of $\mathrm{Di}(\mathrm{a}+\mathrm{b}-)$ and $\mathrm{Di}(\mathrm{a}+\mathrm{b}+)$ were inferred; the $\mathrm{Di}(\mathrm{a}+\mathrm{b}-) /$ $\mathrm{Di}(\mathrm{a}+\mathrm{b}+)$ ratio was $0.004-0.0268$ in Asia while in the Native Americans, the ratio was $0.0135^{-0.1628 . ~}$

We also observed that the $\mathrm{Di}(\mathrm{a}+\mathrm{b}-) / \mathrm{Di}(\mathrm{a}+\mathrm{b}+)$ ratio followed the prevalence of $\mathrm{Di}^{\mathrm{a}}$ positivity (Fig. 1). The $\mathrm{Di}(\mathrm{a}+\mathrm{b}-\mathrm{-}) / \mathrm{Di}(\mathrm{a}+\mathrm{b}+)$ ratio was 0.16 when the $\mathrm{Di}^{\mathrm{a}}$ positivity rate was $75.7 \%$ and 0.004 when the positivity rate was $2.26 \%$. These results suggest a lower prevalence of $\mathrm{Di}^{\mathrm{a}}$ in specific populations, making it difficult to collect $\mathrm{Di}(\mathrm{a}+\mathrm{b}-)$ samples in contrast to populations that have a higher prevalence of $\mathrm{Di}^{\mathrm{a}}$. The agglutinin titres of $\mathrm{Di}^{\mathrm{a}}$ using monoclonal anti- $\mathrm{Di}^{\mathrm{a}}$ were low in populations with lower prevalence of $\mathrm{Di}^{\mathrm{a}}$ compared to those in higher prevalence populations (Fig. 1).

\section{GENOTYPE}

Because $\mathrm{Di}^{\mathrm{a}}$ and $\mathrm{Di}^{\mathrm{b}}$ antigens were identified at nt.2561 in the exon of SLC4AI gene, molecular analysis techniques were used to screen for the Diego genotype.

The Korean minority from Jilin showed the highest frequency of $\mathrm{Di}(\mathrm{a}+\mathrm{b}+)$ with $11.20 \%$, followed by 9.49\% in the Uygur minority from Xinjiang, $8.00 \%$ in blood donors from Guangzhou, and 5.59\% in blood donors from Shenzhen (Table 2). In contrast, the frequency of the rare blood type, $\mathrm{Di}(\mathrm{a}+\mathrm{b}-)$, was $0.45 \%$ in Jilin and was the highest frequency although the sample size was 200 . 
in the Chinese population, 2017, 1(4)

Table 1 Frequencies of $\mathrm{Di}(\mathrm{a}+\mathrm{b}-), \mathrm{Di}(\mathrm{a}+\mathrm{b}+)$, and $\mathrm{Di}(\mathrm{a}-\mathrm{b}+)$ determined from $\mathrm{Di}^{\mathrm{a}}$ positivity rate in Asia and USA

\begin{tabular}{|c|c|c|c|c|c|c|}
\hline \multirow{2}{*}{ Ethnic groups } & \multirow{2}{*}{ Area } & \multirow{2}{*}{$\operatorname{Di}^{\mathrm{a}}(\%)$} & \multicolumn{3}{|c|}{ Estimated frequency $(\%)$} & \multirow{2}{*}{$\begin{array}{l}\operatorname{Di}(a+b-) / \\
\operatorname{Di}(a+b+)\end{array}$} \\
\hline & & & $\operatorname{Di}(a-b+)$ & $\operatorname{Di}(a+b+)$ & $\operatorname{Di}(a+b-)$ & \\
\hline $\operatorname{Han}^{[12]}$ & North China & 11.03 & 88.96 & 10.75 & 0.29 & 0.0268 \\
\hline Dong minority $^{[13]}$ & Southeast China & 2.26 & 97.74 & 2.25 & 0.01 & 0.0044 \\
\hline Zhuang minority $^{[14]}$ & Southeast China & 4.36 & 95.64 & 4.31 & 0.05 & 0.0116 \\
\hline Korean minority ${ }^{[14]}$ & North China & 4.02 & 95.98 & 3.98 & 0.04 & 0.0101 \\
\hline $\operatorname{Han}^{[15]}$ & Taiwan, China & 2.53 & 97.47 & 2.52 & 0.01 & 0.0040 \\
\hline Japanese $^{[7]}$ & Japanese & 10.05 & 89.84 & 9.91 & 0.25 & 0.0252 \\
\hline Korean $^{[17]}$ & Korea & 6.14 & 93.86 & 6.05 & 0.09 & 0.0149 \\
\hline Indian $^{[18]}$ & North India & 4.00 & 96.00 & 3.96 & 0.04 & 0.0101 \\
\hline Zang minority $^{[19]}$ & North China & 5.03 & 95.97 & 4.97 & 0.06 & 0.0125 \\
\hline Manchu minority ${ }^{[19]}$ & North China & 3.33 & 96.66 & 3.29 & 0.03 & 0.0091 \\
\hline Blood donor ${ }^{[20]^{*}}$ & East China (Shanghai) & 8.04 & 91.96 & 7.88 & 0.16 & 0.0203 \\
\hline Arawak native Americans ${ }^{[10]}$ & Venezuela & 5.26 & 94.74 & 5.19 & 0.07 & 0.0135 \\
\hline Kaingang native Americans ${ }^{[10]}$ & Brazil & 54.16 & 45.84 & 48.32 & 5.84 & 0.1209 \\
\hline Parakanã native Americans ${ }^{[21]}$ & Brazil & 75.71 & 24.29 & 65.11 & 10.60 & 0.1628 \\
\hline Chippewa native Americans ${ }^{[22]}$ & USA & 10.81 & 89.18 & 10.54 & 0.28 & 0.0266 \\
\hline Penobscot native Americans ${ }^{[23]}$ & USA & 8.03 & 91.96 & 7.88 & 0.16 & 0.0203 \\
\hline Mexicans $^{[24]}$ & USA & 10.21 & 89.79 & 9.96 & 0.25 & 0.0251 \\
\hline African Americans ${ }^{[18]}$ & USA & 0.12 & 99.88 & 0.12 & 0.00 & 0.0000 \\
\hline Poles $^{[25]}$ & Poland & 0.47 & 99.53 & 0.47 & 0.00 & 0.0000 \\
\hline Inuits $^{[18,26]}$ & Siberia & 20.93 & 79.08 & 19.93 & 0.99 & 0.0497 \\
\hline Inuits $^{[18]}$ & Alaska, Canada & 0.14 & 99.86 & 0.14 & 0.00 & 0.0000 \\
\hline
\end{tabular}

"The frequency of $\mathrm{Di}(\mathrm{a}+\mathrm{b}-), \mathrm{Di}(\mathrm{a}+\mathrm{b}+)$, and $\mathrm{Di}(\mathrm{a}-\mathrm{b}+)$ were inferred from the positivity rate of anti-Di.

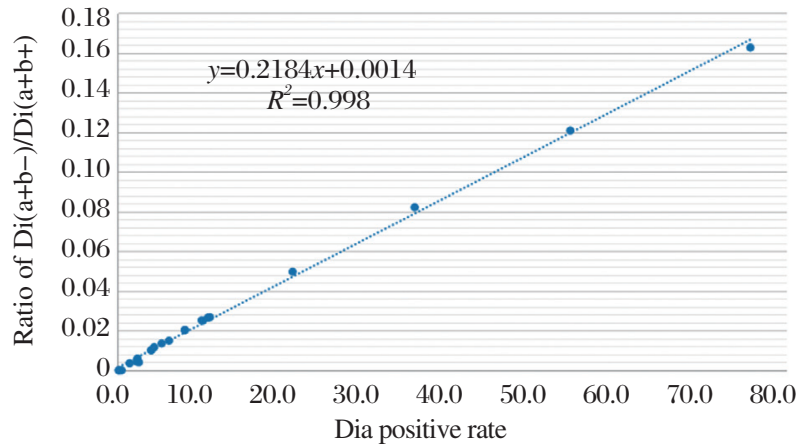

Fig. 1 The $\mathrm{Di}(\mathrm{a}+\mathrm{b}-) / \mathrm{Di}(\mathrm{a}+\mathrm{b}+)$ ratio follows the prevalence of $\mathrm{Di}^{\mathrm{a}}$ positivity rate

\section{ALLOANTIBODIES AGAINST Di $^{\mathrm{a}}$ AND Di $^{\text {b ANTIGENS }}$}

Anti-Di ${ }^{\mathrm{a}}$ and anti-Di ${ }^{\mathrm{b}}$ are often encountered in HDN, with anti-D $\mathrm{i}^{\mathrm{a}}$ being more common than anti$\mathrm{Di}^{\mathrm{b}}$ due to the deficiency of $\mathrm{Di}^{\mathrm{b}}$ antigen being very rare in all ethnic populations. Both anti-Di ${ }^{\mathrm{a}}$ and anti-Di ${ }^{\mathrm{b}}$ are responsible for fatal haemolytic disease. Anti-Di ${ }^{\mathrm{a}}$ production is mainly stimulated by pregnancy and delayed haemolytic transfusion reactions; however, naturally occurring anti- $\mathrm{Di}^{\mathrm{a}}$ has also been reported $^{[10,38-42]}$. We reviewed case reports from China and found that anti-Di ${ }^{\mathrm{a}}$ reaction leads to rash, delayed haemolytic disease and natural occurring also being reported (Table 3). One example of anti- $\mathrm{Di}^{\mathrm{a}}$ reaction was notable in that it resulted in a stillborn foetus. Anti-Di ${ }^{b}$ has also been found responsible for a delayed hemolytic transfusion reactions (HTR) and death ${ }^{[2,43,44]}$. In China, two case reports demonstrated that anti-Di ${ }^{\mathrm{a}}$ induced serve anaemia and fever transfusion reaction (Table 3).

\section{DOSAGE EFFECT}

Few studies have observed the dosage effect of Diego blood group. In this study we used monoclonal anti-Di ${ }^{\mathrm{a}}$ (IMMUCOR GAMMA, Texas, USA) and human-sourced anti-Di ${ }^{\mathrm{b}}$ from two Di(a+b-) immunized patients to examine the agglutinin titres for the genotypes $\operatorname{Di}(a-b+), \operatorname{Di}(a+b+)$, and $\operatorname{Di}(a+b-)$.

The titres of anti-Di ${ }^{a}$ were negative and anti-Dib were $3+$ and $2+$ in five samples of the $\mathrm{Di}(\mathrm{a}-\mathrm{b}+)$ genotype, followed by anti-Di $\mathrm{i}^{\mathrm{a}}$ titres of $1+$ and anti- $-\mathrm{Di}^{\mathrm{b}}$ titres of $2+$ and $1+$ in three samples of the $\operatorname{Di}(a+b+)$ genotype, while the anti- $\mathrm{Di}^{\mathrm{a}}$ titres were $3+$ and anti$\mathrm{Di}^{\mathrm{b}}$ were negative in three samples of the $\mathrm{Di}(\mathrm{a}+\mathrm{b}-)$ genotype(Table 4).

These results may reveal the dosage effect of $\mathrm{Di}^{\mathrm{a}}$ and $\mathrm{Di}^{\mathrm{b}}$ antigens. $\mathrm{Di}(\mathrm{a}+\mathrm{b}-)$ is a very rare blood type in China and this served as the main limitation in the examination of the agglutinin titres to Diego blood group antigens. 
Table 2 Frequencies of $\mathrm{Di}(\mathrm{a}+\mathrm{b}-), \mathrm{Di}(\mathrm{a}+\mathrm{b}+)$, and $\mathrm{Di}(\mathrm{a}-\mathrm{b}+)$ determined from $\mathrm{Di}^{\mathrm{a}}$ positivity rate in Asia and USA

\begin{tabular}{|c|c|c|c|c|}
\hline Ethnic groups & Area & $\operatorname{Di}(\mathrm{a}-\mathrm{b}+) / n(\%)$ & $\operatorname{Di}(\mathrm{a}+\mathrm{b}+) / n(\%)$ & $\mathrm{Di}(\mathrm{a}+\mathrm{b}-) / n(\%)$ \\
\hline Blood donor & East China (Hefei) ${ }^{[27]}$ & $254(98.45)$ & $4(1.55)$ & $0(0.00)$ \\
\hline Blood donor & Southeast China (Shenzhen) ${ }^{[28]}$ & $2821(94.35)$ & $167(5.59)$ & $2(0.07)$ \\
\hline Blood donor & Southeast China (Jiangxi) ${ }^{[29]}$ & $196(98.00)$ & $4(2.00)$ & $0(0.00)$ \\
\hline Blood donor & Southeast China (Guangzhou) ${ }^{[30]}$ & $184(92.00)$ & $16(8.00)$ & $0(0.00)$ \\
\hline Yi minority & Southwest China (Sichuan) ${ }^{[31]}$ & $116(96.67)$ & $4(3.33)$ & $0(0.00)$ \\
\hline Blood donor & North China (Liaoning) ${ }^{[32]}$ & $1529(96.96)$ & $47(2.98)$ & $1(0.06)$ \\
\hline Korean minority & North China (Jilin) ${ }^{[33]}$ & $888(88.8)$ & $112(11.20)$ & $0(0.00)$ \\
\hline Blood donor (Han) & North China (Xian) ${ }^{[34]}$ & $210(95.45)$ & $4(4.09)$ & $1(0.45)$ \\
\hline Blood donor (Han) & East China (Nanjing) ${ }^{[35]}$ & $1913(94.94)$ & $100(4.96)$ & $2(0.10)$ \\
\hline Blood donor & East China (Shanghai) ${ }^{[36]}$ & $366(96.32)$ & $14(3.68)$ & $0(0.00)$ \\
\hline Uygur minority & West China (Xinjiang) ${ }^{[37]}$ & $143(90.51)$ & $15(9.49)$ & $0(0.00)$ \\
\hline
\end{tabular}

Table 3 Alloantibodies against $\mathrm{Di}^{\mathrm{a}}$ and $\mathrm{Di}^{\mathrm{b}}$ antigens in Chinese

\begin{tabular}{|c|c|c|c|c|c|c|c|}
\hline Alloantibody & Area & Age(y) & Gender & $\begin{array}{c}\text { Transfusion } \\
\text { History }\end{array}$ & $\begin{array}{c}\text { Pregnancy } \\
\text { History }\end{array}$ & Clinical Outcome & $\begin{array}{c}\text { Major Immuni- } \\
\text { zation }\end{array}$ \\
\hline Anti-Di ${ }^{b}$ & Liaoling $^{[45]}$ & 54 & $\mathrm{~F}$ & Yes & Yes & Serve anaemia & Pregnancy \\
\hline Anti-Di ${ }^{b}$ & Yunnan $^{[46]}$ & 55 & $\mathrm{~F}$ & Yes & Yes & Transfusion reaction (fever) & Transfusion \\
\hline Anti-Di ${ }^{b}$ & Beijing $^{[47]}$ & 60 & $\mathrm{~F}$ & Yes & Yes & Pre-surgery routine test & Unclear \\
\hline Anti-Di ${ }^{b}$ & Anhui $^{[48]}$ & 25 (mother) & $\mathrm{F}$ & unknown & Yes & Newborn haemolytic disease & Pregnancy \\
\hline Anti-Di ${ }^{\mathrm{a}}$ & Gansu $^{[49]}$ & unknown & $\mathrm{F}$ & No & Yes & Newborn haemolytic disease & Pregnancy \\
\hline Anti-Di ${ }^{\mathrm{a}}$ & Shangdong ${ }^{[50]}$ & 28(mother) & $\mathrm{F}$ & Yes & Yes & Newborn haemolytic disease & Pregnancy \\
\hline Anti-Di ${ }^{\mathrm{a}}$ & Hubei $^{[51]}$ & unknown & $\mathrm{F}$ & Unknown & Yes & Newborn haemolytic disease & Pregnancy \\
\hline Anti-Di ${ }^{\mathrm{a}}$ & Jiangsu $^{[52]}$ & 33(mother) & $\mathrm{F}$ & No & Yes & Stillborn foetus & Pregnancy \\
\hline Anti-Di ${ }^{\mathrm{a}}$, anti-E & Beijing $^{[53]}$ & 65 & M & Yes & - & Pre-surgery routine test & Transfusion \\
\hline Anti-Di ${ }^{\mathrm{a}}$ & Jiangsu $^{[54]}$ & 25 & $\mathrm{~F}$ & No & Yes & Pre-caesarean test & Pregnancy \\
\hline Anti-Di ${ }^{\mathrm{a}}$, anti-D & Beijing $^{[55]}$ & 76 & $\mathrm{~F}$ & No & Yes & Pre-transfusion & Transfusion \\
\hline Anti-Di ${ }^{\mathrm{a}}$ & Shangdong ${ }^{[56]}$ & 28 & M & Yes & - & Rash & Transfusion \\
\hline Anti-Di ${ }^{\mathrm{a}}$ & Hubei $^{[58]}$ & 55 & M & Yes & - & Pre-surgery routine test & Transfusion \\
\hline Anti-Di ${ }^{\mathrm{a}}$, anti-E & Shanghai $^{[59]}$ & 65 & M & No & - & Routine transfusion test & Natural immune \\
\hline
\end{tabular}

Table 4 The agglutinin titres of $\mathrm{Di}(\mathrm{a}-\mathrm{b}+), \mathrm{Di}(\mathrm{a}+\mathrm{b}+)$ and $\mathrm{Di}(\mathrm{a}+\mathrm{b}-)$ by anti-Di ${ }^{\mathrm{a}}$ and anti-Di

\begin{tabular}{cccc}
\hline Genotype & $\begin{array}{c}\text { Monoclonal } \\
\text { anti-Di }\end{array}$ & $\begin{array}{c}\text { Human resourced } \\
\text { anti-Di }{ }^{\mathrm{b}}-1\end{array}$ & $\begin{array}{c}\text { Human resourced } \\
\text { anti-Di }^{\mathrm{b}}-2\end{array}$ \\
\hline Di(a-b+) & neg & $3+$ & $2+$ \\
Sample1 & neg & $3+$ & $2+$ \\
Sample2 & neg & $3+$ & $2+$ \\
Sample3 & neg & $3+$ & $2+$ \\
Sample4 & neg & $3+$ & $2+$ \\
Sample5 & & $2+$ & $1+$ \\
\hline Di(a+b+) & $1+$ & $1+$ & $1+$ \\
Sample1 & $1+$ & $2+$ & $1+$ \\
\hline Sample2 & $1+$ & & neg \\
\hline Sample3 & & neg & neg \\
\hline Di(a+b-) & $3+$ & neg & neg \\
\hline Sample1 & $3+$ & neg & \\
\hline Sample2 & $3+$ & &
\end{tabular}

\section{FUTURE PERSPECTIVES}

Although the application of genotyping to the Diego blood group was a useful tool to investigate the frequency and estimate the agglutinin titres of anti-
$\mathrm{Di}^{\mathrm{a}}$ and anti- $\mathrm{Di}^{\mathrm{b}}$ to $\mathrm{Di}^{\mathrm{a}}$ and $\mathrm{Di}^{\mathrm{b}}$ antigens, respectively, a discussion on the existence of the dosage effect in the Diego blood group is necessary. Our study offered evidence to confirm the dosage effects in the Diego blood group. Further studies, however, especially on Native Americans living in Brazil, are needed to investigate the dosage effect.

Since the alloantibodies against $\mathrm{Di}^{\mathrm{a}}$ and $\mathrm{Di}^{\mathrm{b}}$ antigens are majorly stimulated by pregnancy and often cause HDN and the association between alloantibodies and HDN associated with HLA-DRB1 and DQB1 alleles has also previously been reported. Anti- $\mathrm{Di}^{\mathrm{a}}$ and anti-Di ${ }^{\mathrm{b}}$ reactions causing adverse clinical outcomes may be observed at immunity-associated genes by methods, such as HLA or KIR typing ${ }^{[60-63]}$.

\section{CONCLUSIONS}

The $\mathrm{Di}^{\mathrm{a}}$ antigen is an important antigen in the Chinese population and the $\operatorname{Di}(a+b+)$ is the major genotype in $\mathrm{Di}^{\mathrm{at}}$ Chinese. Our study noted that $\mathrm{Di}^{\mathrm{a+}}$ Chinese is more likely to show a lower agglutinin titre than $\mathrm{Di}^{\text {at }}$ foreigners, such as Native Americans 
in the Chinese population, 2017, 1(4)

from Brazil. Anti-Di ${ }^{\mathrm{a}}$ and anti-Di ${ }^{\mathrm{b}}$ were majorly responsible for HDN while a stillborn foetus resulted from an anti- $\mathrm{Di}^{\mathrm{a}}$ reaction; transfusion reactions such as fever and rash were also reported in the Chinese population.

\section{References}

[1] Layrisse M, Arends T, Dominguez Sisico R. Nuevo gruposanguí neoencontradoendescendientes de Indios. Acta Med Venez, 1955, 3: 132-8.

[2] Thompson PR, Childers DM, Hatcher DE. Anti-Di ${ }^{\mathrm{b}}$ : first and second examples. Vox Sang, 1967, 13: 31-8.

[3] Tanner MJA, Martin PG, High S. The complete amino acid sequence of the human erythrocyte membrane anion - transport protein deduced from the cDNA sequence. Biochem J, 1988, 256: 703-12.

[4] Lux SE, John KM, Kopito RR, et al. Cloning and characterization of band 3, the human erythrocyte anionexchange protein (AE1). Proc Natl Acad Sci USA, 1989, 86: 9089-93.

[5] Bruce LJ, Anstee DJ, Spring FA, et al. Band 3 Memphis variant II. Altered stilbene disulfonate binding and the Diego $\left(\mathrm{Di}^{\mathrm{a}}\right)$ blood group antigen are associated with the human erythrocyte band 3 mutation Pro $854 \rightarrow$ Leu. $J$ Biol Chem, 1994, 269: 16155-8.

[6] Schofield AE, Martin PG, Spillet D, et al. The structure of the human red blood cell anion exchanger (EPB3, AEl, Band 3) gene. Blood, 1994, 84: 2000-12.

[7] Miyazaki T, Sato S, Kato T, et al. Human anti-Di ${ }^{\text {a }}$ monoclonal antibodies for mass screening. Immunohematology, 2000, 16: 78-81.

[8] Reid ME, Lisowska E, Blanchard D. Section 3: epitope determination of monoclonal antibodies to glycophorin A and glycophorin B. Coordinator's report. Antibodies to antigens located on glycophorins and band 3. Transfus Clin Biol, 2002, 9: 63-72.

[9] Biro V, Garratty G, Johnson CL, et al. Depressed blood group antigens on red cells from a Mexican donor. Transfusion, 1983, 23: 65-6.

[10] Levine P, Robinson EA, Layrisse M, et al. The Diego blood factor. Nature, 1956, 177: 40-1.

[11] Mochizuki K, Ohto H, Hirai S. Hemolytic disease of the newborn due to anti-Di $\mathrm{i}^{\mathrm{b}}$ : a case study and review of the literature. Transfusion, 2006, 46: 454-60.

[12] Yuan Y, Xu J, Zhang Z, et al. Distribution of Kell, Kidd, Diego, Duffy, Lutheran and Xg blood group systems in the Han nationality of North China.. Acta Genetica Hereditas(in Chinese), 1982, 5: 395-401.

[13] Yuan Y. Distribution of nine blood group systems and $\mathrm{ABH}$ secretion in the Dong minority. Acta Anthropologica Sinica(in Chinese), 1984, 3: 277-84.

[14] Yuan Y. Distribution of eight blood group systems and $\mathrm{ABH}$ secretion in Mongolian, Korean and Zhuang nationalities in China. Ann Hum Biol, 1984, 11: 377-88.

[15] Fraser GH. Distribution of blood group systems in Han of Taiwan. J Med Genet, 1965, 2: 21-3.

[16] Nakajima H. Distribution of blood group systems in mi- nority of Taiwan. J Hum Genet, 1971, 11: 244-51.

[17] Won CD, Shin HS, Kim SW, et al. Distribution of hereditary blood factors among Koreans residing in Seoul, Korea. Am J Phys Anthrop, 1960, 18: 115-24.

[18] Mourant AE, Kopec AC, Domaniewska-Sobczak K. The distribution of the human blood groups and other polymorphisms. 2nd ed. London: Oxford University Press, 1976.

[19] Ai J. The distribution of Kidd, Duffy, Kell, Xg, Rh, Diego and $\mathrm{P}$ blood group systmes among Yi, Zang and Manchu minorities. Acta Anthropologica Sinica, 1988, 7: 191-9.

[20] Zhu Z, Sheng W, Cheng H. Rare blood group screening among Chinese blood donors in Shanghai area. Chin J Blood Transfusion(in Chinese), 2002, 15: 232-3.

[21] Baleotti W Jr, Rios M, Reid ME. A novel DI*A allele without the band 3-Memphis mutation in Amazonian Indians. Vox Sang, 2003, 84: 326-30.

[22] Lewis M, Ayukawa H, Chown B, et al. The blood group antigen Diego in North American Indians and in Japanese. Nature, 1956, 177: 1084.

[23] Allen FH, Corcoran PA. Blood groups of the Penobscot Indians. Am J Phys Anthrop, 1960, 18: 109-14.

[24] Edwards-Moulds JM, Alperin JB. Studies of the Diego blood group among Mexican-Americans. Transfusion, 1986, 26: 234-6.

[25] Kusnierz-Alejska G, Bochenek S. Haemolytic disease of the newborn due to anti-Di $\mathrm{i}^{\mathrm{a}}$ and incidence of the $\mathrm{Di}^{\mathrm{a}}$ antigen in Poland. Vox Sang, 1992, 62: 124-6.

[26] Tills D, Kopec AC, Tills RE. The distribution of the human blood groups and other polymorphisms, Suppl. 1. Oxford: Oxford University Press, 1983.

[27] Lu R, Hu Z, Liu Z. Establishment and application of PCR-SSP for detecting Diego blood group. J Clin Transfus Lab Med(in Chinese), 2011, 13: 310-2.

[28] Yang B, Su Y, Yu Q, et al. Molecular genetic analysis of Diego blood group Dia and $\mathrm{Di}^{\mathrm{b}}$ in Chinese Han Population. Journal of Forensic Medicine(in Chinese), 2007, 23: $283-5$.

[29] Xiao L, Wu H, Li G, et al. The distribution of Diego genotype in Hans at Jiangxi. Experimental and Laboratory Medicine(in Chinese), 2010, 28: 427.

[30] Wen J, Fu Y, Luo G, et al. Polymorphism of Diego blood group system in Guangzhou Han population. Chin J Blood Transfusion(in Chinese), 2015, 28: 663-665.

[31] Xin Y, Tian L, Song N, et al. Molecular genetic analysis of ABO, MNS, Duffy, Diego, Lutheran, Kidd, Dombrock and Colton blood group systems in Sichuan Yi population. Chin J Blood Transfusion(in Chinese), 2013, 26: 41-4.

[32] Liu Y, Niu M. Investigation on Diego gene frequency in Chinese Han population. Lab Med Clin(in Chinese), 2010, 7: 308-11.

[33] Jiao L, Chen L, Han Y, et al. The distribution of Diego genotype in Korean at Jilin. Clinical Journal of Laboratory and Diagnosis(in Chinese), 2015, 19: 2129-30.

[34] Liu M, Jiang D, Liu S. Diego blood group typing of Han 
nationality in $\mathrm{Xi}^{\prime}$ an City. Journal of Xi'an Jiaotong University (Medical Sciences) (in Chinese), 2003, 24: 348-9.

[35] Chen Y, Ma L, Liu Y. A survey for Colton and other 3 rare blood group systems in Chinese Nanjing Han Population. Journal of Experimental Hematology(in Chinese), 2015, 23: 1474-7.

[36] Wu G, Liu D, Yu G, et al. The distribution of Diego genotype in China. Hereditas(in Chinese), 1986, 8: 37-9.

[37] Lin GY, Du XL, Shan JJ, et al. Molecular genetic analysis of genes from MNS, Duffy and Kell blood groups in the China Xinjiang Uygur population. Chinese Journal of Tissue Engineering Research(in Chinese), 2016, 20 : $123-7$.

[38] Riches RA, Laycock CM, Poole J. Anti-Dia causing HDN in an English family. Non-linkage of Diego and Colton genes is demonstrated. $20^{\text {th }}$ Congr Int Soc Blood Transfus, 1988: 299 [Abstracts].

[39] Kusnierz-Alejska G, Bochenek S. Haemolytic disease of the newborn due to anti-Di $\mathrm{i}^{\mathrm{a}}$ and incidence of the $\mathrm{Di}^{\mathrm{a}}$ antigen in Poland. Vox Sang, 1992, 62 : 124-6.

[40] Graninger W. Anti- $\mathrm{Di}^{\mathrm{a}}$ and the $\mathrm{Di}^{\mathrm{a}}$ blood group. Antigen found in an Austrian family. Vox Sang, 1976, 31: 131-5.

[41] Simmons RT, Albrey JA, Morgan JAG, et al. The Diego blood group: anti-Di ${ }^{\mathrm{a}}$ and the $\mathrm{Di}(+)$ blood group antigen found in Caucasians. Med J Austral, 1968, 1: 406-7.

[42] Ting JY, Ma ESK, Wong KY. A case of severe haemolytic disease of the newborn due to anti- $\mathrm{Di}^{\mathrm{a}}$ antibody. Hong Kong Med J, 2004, 10: 347-9.

[43] Perkins JT, Johnson ST, Ahmed S. Hemolytic transfusion reaction (HTR) due to anti-Di ${ }^{\mathrm{b}}$. Transfusion, 2009, 49 (Suppl.): 130A [Abstract].

[44] Mochizuki K, Ohto H, Hirai S, et al. Hemolytic disease of the newborn due to anti-Dibi : a case study and review of the literature. Transfusion, 2006, 46: 454-60.

[45] Wang H, Su Y, Xu M. A case report of rare anti-Di ${ }^{\text {b }}$. Chin J Blood Transfusion(in Chinese), 2007, 20: 61-2.

[46] Su P, Yang T, Wang C, et al. A case report of rare antiDib and Meaninigful screening to genotype of Diego. Chin J Blood Transfusion (in Chinese), 2012, 139: E3-011.

[47] Lin YS, Zhang Y, Xu Z, et al. Identification of antibody against highly prevalent antigens through commercial genotype kit: a case report of anti-Dib. Chin J Blood Transfusion(in Chinese), 2007, 29: 1330-2.

[48] Hu K, Liu Z, Fang Q, et al. A case report of Anti-Di ${ }^{\text {b }}$ and $\mathrm{ABO}-$ incompatibe induced newborn hemolytic disease. Chin J Clin Lab Sci(in Chinese), 1996, 14: 215.
[49] Lu H, Zhu H, Xu Q, et al. Hemolytic disease of a newborn due to rare alloantibody of anti-Di ${ }^{\text {b }}$ : blood screening and family pedigree analysis. Chin J Blood Transfusion(in Chinese), 2015, 28: 21-3.

[50] Xu R. A case report of anti-Di ${ }^{\mathrm{a}}$ induced newborn hemolytic disease. Chinese Journal of Neonatology(in Chinese), 2009, 24: 385.

[51] Jiang M, Ren M, He M, et al. A case of hemolytic disease of newborn due to anti-Di ${ }^{\mathrm{a}}$. J Clin Hematol(in Chinese), 2016, 20: 687-8.

[52] Ye D, Wu C. A case report of anti-Di ${ }^{\mathrm{a}}$ induced stillborn foetus. J Clin Hematol(in Chinese), 1990, 2: 89-90.

[53] Liu Y. Case analysis of incompatibility in blood crossmatching induced by anti-D $\mathrm{i}^{\mathrm{a}}$ and anti-E antibodies. Int J Lab Med(in Chinese), 2015, 36: 369-70.

[54] Chen X, Lin J, Wen H. A case report of anti-Dia in Han. Chin J Clin Lab Sci(in Chinese), 2014, 32: 879-80.

[55] Guo N, Liu C, Bai J, et al. A case report of anti-Di ${ }^{\mathrm{a}}$ and anti-D. Beijing Medical Journal(in Chinese), 2012, 34: 924-5.

[56] Wang L, Song T, Yu J, et al. A case report of alloantibody against $\mathrm{Di}^{\mathrm{a}}$ antigen. Chin J Blood Transfusion(in Chinese), 2013, 26: 1039.

[57] Li C, Tong C, Pan D. A case report of anti-- $\mathrm{Di}^{\mathrm{a}}$ induce delay hemolytic reaction. Chin J Blood Transfusion(in Chinese), 2003, 16: 285-6.

[58] Ho Z, Wang Z, Ye H. A case report of anti-Dia. J Clin Hematol (in Chinese), 2011, 12: 756.

[59] Li W, Liao H, Duan H, et al. A case report of anti-Di ${ }^{\mathrm{a}}$ and anti-E. Chin J Blood Transfusion(in Chinese), 2012, 15: 1040-2.

[60] Sun A, Fang K, Su Y, et al. Study on the correlation of HLA-DRB1 alleles and hemolytic disease of newborn. Pract Prev Med(in Chinese), 2014, 21: 649-51.

[61] Sun A, Fang K, Su Y. Study on the correlation of HLADQB1 alleles and hemolytic disease newborn. MMJC(in Chinese), 2014, 16: 5-8.

[62] Lin YS, Xu Z, Li X. Association of HLA-DRB1 and HLA-DQB1 alleles with red blood cell auto-immunization in the Chinese population. Asia-Pacific Journal of Blood Types and Genes, 2017, 1(2):31-4.

[63] Lin YS, Xu Z, Chang H. Association of HLA-DRB1 and DQB1 alleles with red blood cell alloimmunization in Chinese. Asia-Pacific Journal of Blood Types and Genes, 2017, 1(3):13-7.

(Received 15 November 2017, Revised 02 December 2017, Accepted 06 December 2017) 